\title{
Two Galatian Cults in Dacia
}

\author{
Stephen MITCHELL*
}

\section{Zeus Erosenos - Iuppiter Erusenus}

One of the unpublished inscriptions housed in the Roman Baths at Ankara, is a small crudely finished column of andesite stone, height 1.15; diameter 0.38 . It currently lies at the rear of the excavated area close to the western boundary fence of the archaeological park and has no inventory number. During my work on the epigraphic collection at Ankara I was unable to find out anything about the stone's provenance, but the material itself is typical of the region around and to the north of Ankara. The column has no ornamentation, but the area where the inscription has been carved is rougher than the rest of the column. In addition, there are indistinct traces of lettering below the final line of the legible text, which suggests that the stone may have previously carried another inscription, which was then crudely erased. Alternatively, the mason may have made mistakes in the cutting, which then had to be corrected. The letters are between four and five centimetres high and have cursive forms for epsilon, sigma, and omega (see fig. 1: photo of stone; and fig. 2: photo of squeeze). The text reads:

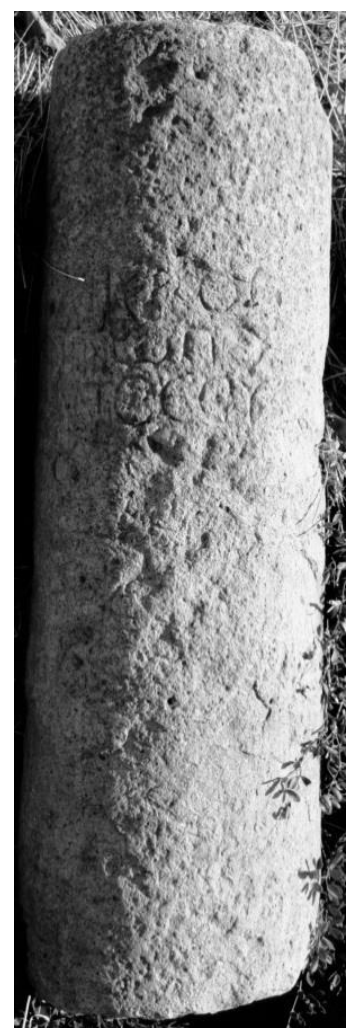

Fig. 1

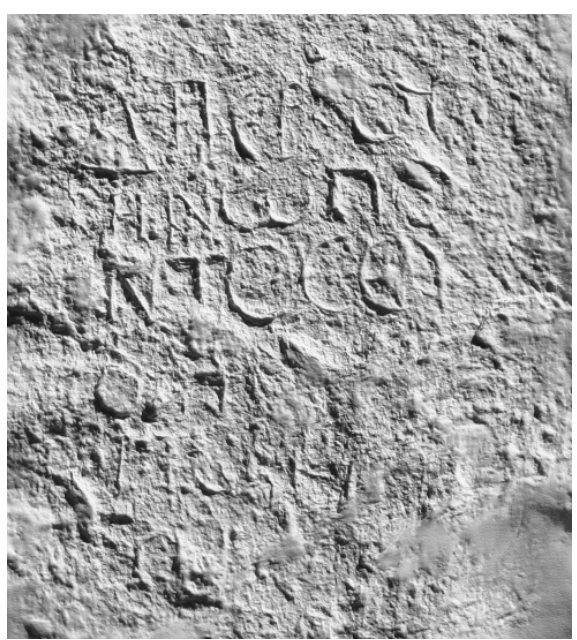

Fig. 2

$\Delta \iota{ }^{\prime} \mathrm{\rho} \rho \circ \sigma^{-}$

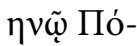

$v \tau O \varsigma \varepsilon \dot{-}$

$4 \quad[\chi] \eta \dot{~}$

"Pontus made a vow for Zeus Erosenos."

1: there is a gap between the rho and the omicron with an apparent trace of a letter from the previous

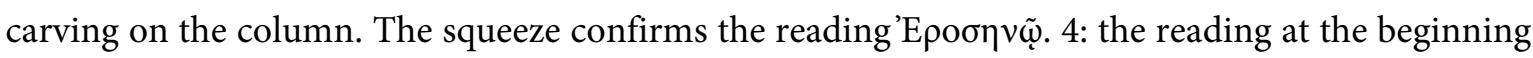

\footnotetext{
* Emeritus Prof. Dr. Stephen Mitchell, University of Exeter, the Department of Classics and Ancient History, Exeter UK EX4 4QJ (mitchank@gmail.com).
} 
of this line is very indistinct, and the squeeze suggests an omicron rather than a chi. There are apparently traces of two lines of an earlier text after this line.

The inscription should probably date to the second century AD and this would suit the letter forms. The dedicator had not received the pseudo-praenomen Aurelius, and the text should belong before $A D$ 212. On the other hand, inscriptions from Ancyra and North Galatia in general were relatively unusual before the second century, and an earlier date is unlikely. The name of the dedicator is not common. According to LGPN, the Latin form Pontus appears in an inscription of Pompeii in the first century $\mathrm{BC}$ or first century $\mathrm{AD}$ (CIL IV 6830; however, this may denote the geographical region), while Пóvтoৎ is attested at Samos in the first century BC (IG XII.6.1, 464, 10) and at Cos at an uncertain date (IG XII.4.3, 1397). A Lucius Marcius Pontus is attested in a long list of persons who made a dedication at Rome to the Pax Aeterna of the emperor Vespasian and his household (CIL VI 36747e). Other Latin examples are attested at Theveste in Africa (CIL VIII 16662; fourth or fifth century) and at Puteoli in Campania (CIL X 2590). The personal name doubtless derived from the ancient name for the Black Sea, Pontos, which itself derived from a non-Greek root meaning a way or a path, usually over sea or water. ${ }^{1}$

Although no other dedications to Zeus Erosenus have been reported from Asia Minor, the cult is attested by two Latin texts from Roman Dacia. One of these is CIL III 859 (ILS 4083) from near ClujClausenberg, the site of Napoca in Dacia:

\author{
I. O. M. \\ Eruseno \\ Aur. Alex- \\ 4 ander \\ Aurelius Alexander willingly paid his vow to Iu- \\ piter Optimus Maximus Erusenus. \\ $\mathrm{v}$ (otum) s(olvit) l(ibens).
}

Mommsen, followed by Dessau, recognized from the Greek adjectival ending -enus that this should be one of the cults introduced by settlers from Asia Minor to Dacia, and suggested that it derived from Eriza in Caria (Livy 38.14. 1; Pliny, NH 10.43, 124). However, the ethnic corresponding to Eriza was Erizenus. ${ }^{2}$ Moreover, all the attested Dacian cults that originated in Asia Minor came from Galatia or from parts of Bithynia and Paphlagonia that bordered Galatia. Aurelius Alexander should be a member of an emigrant Galatian family, whose origins can now be traced to the Ankara region.

A small altar $(0.37 \times 0.32 \times 0.19$; letters $0.03-055)$ dedicated to the same cult has been recorded in the territory of Alburnus Maior in the mining district of Rosia Montana (CIL III 7829; Inscr. Dac. Rom. III.3, 410; C. Ciongradi, Die römischen Steindenkmäler aus Alburnus Maior [Cluj-Napoca 2009], 69 no. 66). The stone is now stored in the depot of the Museum of Dacian and Roman Civilisation at Deva, and the text reads (fig. 3. Lupa 17717).

\footnotetext{
${ }^{1}$ Moorhouse 1940; Allen 1947; Mitchell 2002.

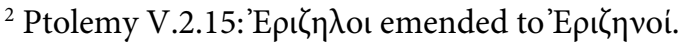




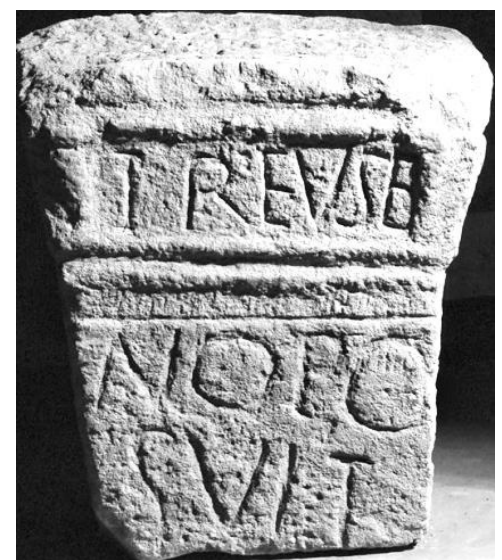

I. REVSE I(ovi) $\langle$ Er $>$ use-

NO PO no po-

SVIT suit

-... $[--]$

... set this up for Iupiter Erusenus.

Fig. 3

1: the first letter was interpreted as a $\mathrm{T}$ in CIL, and T(ito) Reuseno is favoured in the on-line editions of the text (Claus-Slaby Datenbank EDCS-28400531; EDH 046111). However, this would be an irregular Roman name formation, and Reusenus lacks convincing parallels. I. Russu, the editor of the corpus of Dacian inscriptions, hesitated between reading the initial letter as T or I. In the former case it could be interpreted as T(itus) followed by Reusenus, or as Treusenus, but he preferred the reading I(ovi), accepting that the initial letters of the unfamiliar ethnic adjective Eruseno were reversed by the stone cutter. 3: the name of the dedicator doubtless followed the verb.

Following Russu, this should be interpreted as another second or third century dedication to Iuppiter Erusenus. It came from a sanctuary in the mining district of Rosia Montana, like several other votive texts put up by immigrants from Galatia or the neighbouring regions, as discussed in the commentary to the following text.

\section{Zeus of the Seven Villages.}

Another small altar $(0.61 \times 0.28)$ from the area of the Rosia Montana gold mines on the territory of Alburnus Maior was published with the following readings and has been interpreted as a dedication to an otherwise unattested Zeus Sittakomikos: Daicoviciu 1941, 303 no. 5; Bull. ép. 1943, 48; AE 1944, 26; Noeske 1977, 373-426: 381 no. 16; SEG 25, 831; Inscr. Daciae Romanae III.3, 409; Ruscu 2003, 16 no. 7. See fig. 4.

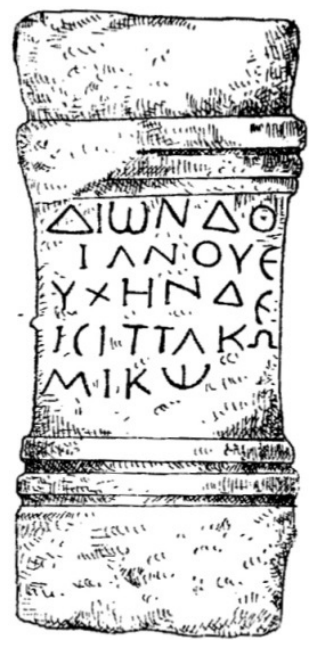

$\Delta \mathrm{i} \omega v \Delta \mathrm{O}$

I $\Lambda$ NOY $\varepsilon-$

ט̉xท่̀ $\Delta \varepsilon-$

4 і $\operatorname{Cı\tau } \tau \alpha \kappa \omega-$

$\mu \iota \kappa \tilde{\omega}$. 
The altar was found on a hill called Carpen with four other altars with Greek inscriptions, dedicated to Zeus Narenos, Zeus Sarnendenos and Zeus Kimistenos, and they doubtless all came from the same ancient sanctuary. ${ }^{3}$ The reading of the text should be corrected in the light of a dedication found by I. W. Macpherson at the Yukarı Iğde Ağaç, on the territory of the Choria Considiana, an imperial estate in western Galatia, which refers to a cult of Zeus of the Seven Villages (RECAM II, 37; see fig. 5). The text is on the pediment and shaft of an altar, decorated with a garland and a bull's head, which has been deliberately damaged.

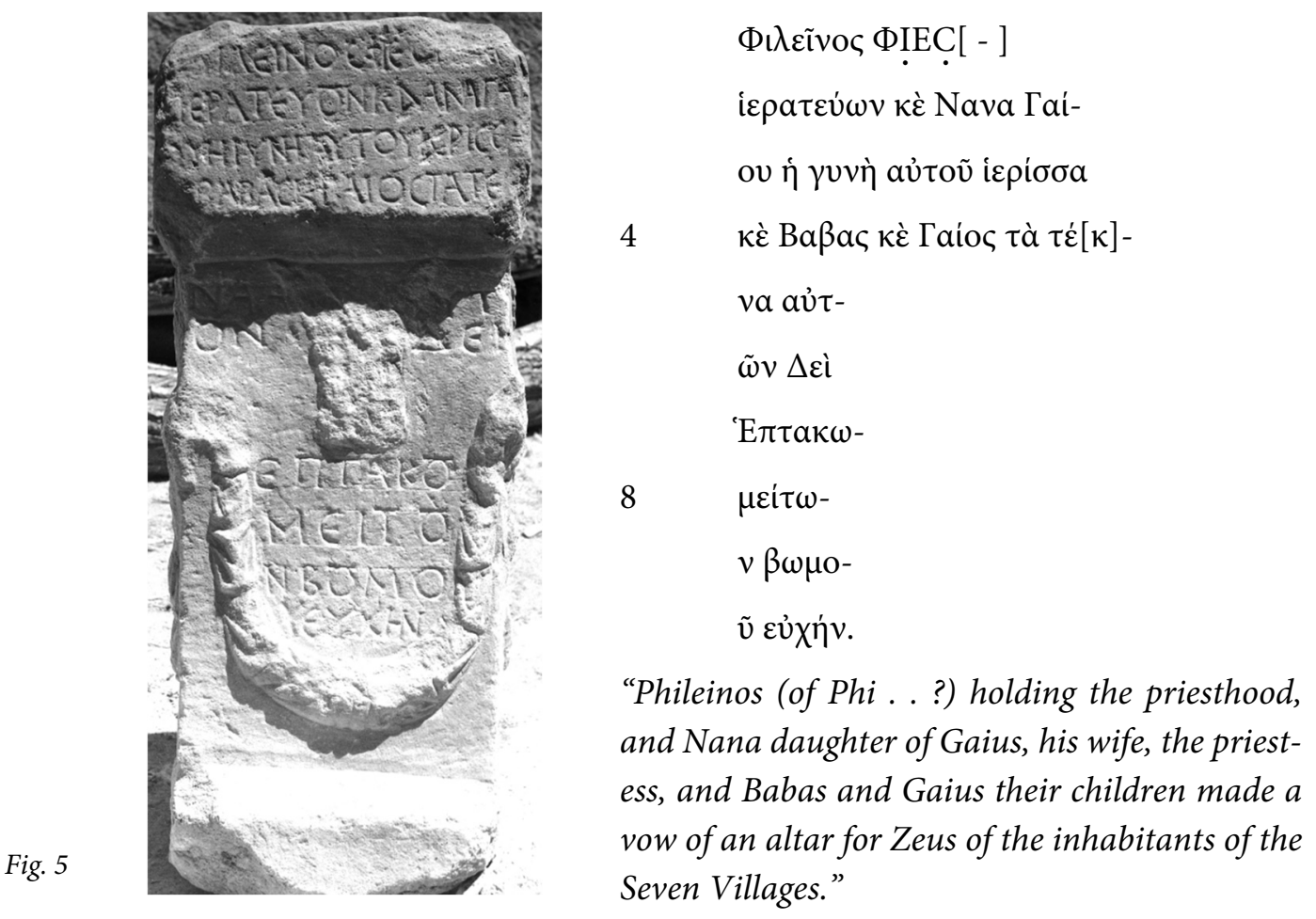

The seven villages certainly belonged to the imperial estate called the choria Considiana based at Yukarı Iğde Ağaç. ${ }^{4}$ The name can also be recognized in a slightly changed form on the Dacian dedication, which should be read as:

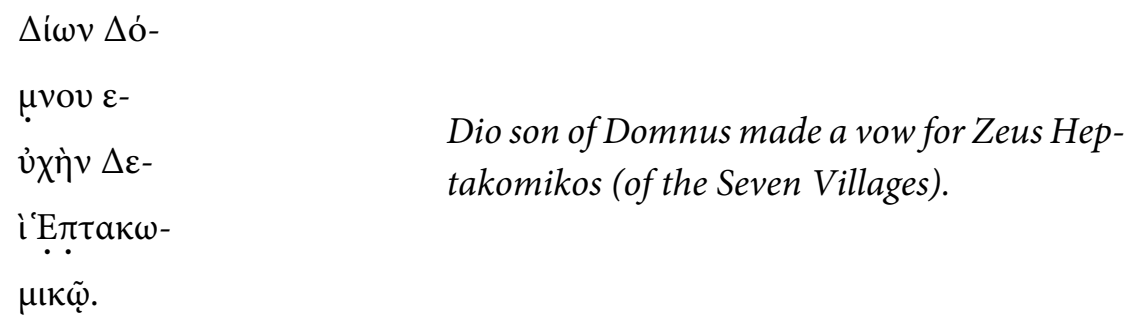

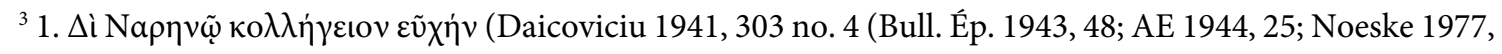

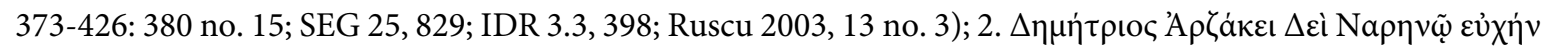
(Daicoviciu 1941, 302 no. 2; Bull. Ép. 1943, 48; AE 1944, 23; Noeske 1977, 373-426: 381 no. 16; SEG 25, 828;

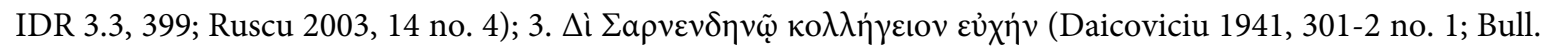
Ép. 1943, 48; AE 1944, 22; Noeske 1977, 373-426: 380 no. 14; SEG 25, 830; IDR 3.3, 400; Ruscu 2003, 14 no. 5.

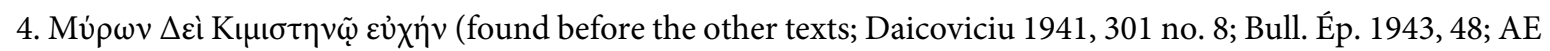
1944, 20; Noeske 1977, 380 no. 13; SEG 25, 825; IDR 3.3, 432; Ruscu 2003, 17 no. 8).

${ }^{4}$ See RECAM II 37 comm., and Mitchell 1993, I, 153. 


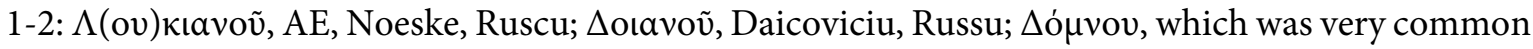
in Galatia, can be restored with confidence. 4: cursive epsilon should be read instead of sigma and the following letters iota tau as a $p i$, so that $\Sigma ı \tau \tau \alpha \kappa \omega \mu$

Like the cults of Zeus Narenus and Zeus Sarnendenus, which originated in western Galatia, the worship of Zeus of the Seven Villages was also introduced to the mining district of Dacia by Galatian immigrants. In fact a recent survey of Galatia's western borderland with Asia and Bithynia, between the Sangarius (Sakarya) and Tembris (Porsuk) rivers, where the choria Considiana was situated, has included the discovery near the village of Çalçak of a necropolis belonging to a community of quarrymen and their families. ${ }^{5}$ It is likely that most of the Galatian colonists of the Rosia Montana mining district were already mine or quarry workers, whose skills and experience could be used in the rapid exploitation of the newly conquered province, especially its gold mines.

All these inscriptions retained the Greek language, and included personal names which were characteristic or common in central Asia Minor. Domnos was one of the commonest names in Galatia (see RECAM II index). ${ }^{6}$ These are indications that the dedications belong to the early period of the Galatian settlement in Dacia, probably to the first generation after the Trajanic conquest. The form

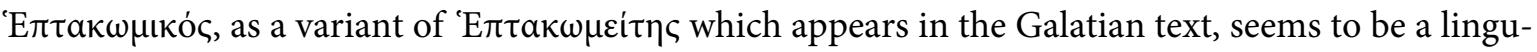
istic aberration. The Greek adjective $\kappa \omega \mu$ «ó and referred to comic acting. However, in the present context there can be no doubt that it relates to the noun $\kappa \omega \mu \eta$, simply meaning 'of the village'. Perhaps Dio son of Domnus was a first-language speaker of Celtic Galatian with an imperfect grasp of Greek, and there was no one available in Dacia to correct him.

It is interesting to trace the development of these Asia Minor cults through their linguistic format. The first Galatian settlers from the east used Greek for their dedications (although it is quite likely that their spoken language at this date was a form of Celtic). Subsequently, the community became Latin speaking, as is shown by the simple votive text for Iovi Eruseno. By the late second and third centuries all the epigraphic evidence for Galatian settlers in Dacia is in Latin. The dedications made in cities by members of the municipal governing class, who were of Galatian origin but had now become Roman citizens, show how these obscure and modest Asia Minor cults for Zeus achieved much more prominent status by being combined with the worship of Iupiter Optimus Maximus. The dedication to Iovi Optimo Maximo Eruseno by Aurelius Alexander can be compared to the Latin dedications of the late second or early third century set up at Apulum for I. O. M. Taviano (CIL III 1088; IDR III.5, 228), I. O. M. Bussumario (CIL III 14215, 15; ILS 4621; IDR III.5, 206), I. O. M. Soli Bussurigio (AE 1944, 32; IDR III.5, 207) and I. O M. Cimisteno (AE 1964, 186; IDR III.5, 208; AE 1964, 185; IDR III.5, 209).

\footnotetext{
${ }^{5}$ Güney 2016, 125-39.

${ }^{6}$ For an interpretation of the name as derived from the Celtic Dumn- root, see Coşkun 2013, 89.
} 


\section{Bibliography}

Allen 1947

W. S. Allen, The Name of the Black Sea, Classical Quarterly 41, 1947, 86-88.

Coşkun 2013

A. Coşkun, Histoire par les noms in ancient Galatia, in: R. Parker (ed.), Personal Names in Ancient Anatolia, Oxford 2013, 79-106.

Daicoviciu 1941

C. Daicoviciu, Neue Mitteilungen aus Dazien (Funde und Einzeluntersuchungen), Dacia 7/8, 1941, 299-336.

Güney 2016

H. Güney, New inscriptions from the Choria Considiana: Çalçak Roman necropolis, Anatolian Studies 66, 2016, 125-139.

Mitchell 1993

S. Mitchell, Anatolia. Land, Men, and Gods in Asia Minor, Vol I-II, Oxford 1993.

Mitchell 2002

S. Mitchell, In search of the Pontic community in Antiquity, in: A. Bowman et al. (edd.), Representations of Empire. Rome and the Mediterranean World (Proc. British Academy 114), Oxford 2002, 35-64.

Moorhouse 1940

A. C. Moorhouse, The Name of the Euxinus Pontus, Classical Quarterly, 1940, 123-128.

Noeske 1977

H. C. Noeske, Studien zur Verwaltung und Bevölkerung der dakischen Goldbergwerke in römischer Zeit, Bonner Jahrbücher 177, 1977, 373-426.

Ruscu 2003

L. Ruscu, Corpus Inscriptionum Graecarum Dacicarum, Debrecen 2003.

\section{Figures:}

Fig. 1. Inscribed votive column for Zeus Erusenus, Ankara (S. Mitchell).

Fig. 2. Squeeze of inscription for Zeus Erusenus, Ankara (S. Mitchell).

Fig. 3. Latin dedication to Iuppiter Erusenus (CIL III 7829; Inscr. Dac. Rom. III.3, 410; photo @ Deva - Muzeul Civilizatiei Dacice si Romane Fotograf: Ortolf Harl [2010]).

Fig. 4. Votive altar from Rosia Montana, territory of Alburnus Maior (Figure from Inscr. Daciae Romanae III.3, 409).

Fig. 5. Votive altar for Zeus of the Seven Villages, western Galatia (RECAM II, 37; Photo I. W. Macpherson). 


\section{Dacia'da İki Galat Kültï \\ Özet}

Ankara veya çevresinden ele geçen bir yazıt Zeus Erusenos'a bir adağı içermektedir. Bu tanrı, Roma Dönemi Dacia'sında (Romanya) bulunan iki Latince yazıtta da belgelenmiştir ve bu kült, tıpkı Galatia ya da doğu Bithynia' daki diğer yerel kültler gibi, İmparator Traianus tarafından fethedilip Roma topraklarına dahil edilen yeni eyalet Dacia'ya Asia Minor'dan getirilmiştir. Dacia'da içeriğinde Zeus Sittakomikos'a adak yapıldığı okunan Yunanca adak yazıtındaki ifade Zeus Heptakomikos olarak değiştirilmeli ve batı Galatia'da Chôra Considiana olarak adlandırılan imparator arazisinde tapınım gören Yedi Köyler Zeus'u (Zeus Heptakomeitôn) kültü ile özdeşleştirilmelidir. Muhtemelen Dacia'da pek çok Galatialı göçmen maden ve taş ocaklarında çalışmaktaydı.

Anahtar Sözcükler: Ankyra; Dacia'daki Galatialı göçmenler; dil kullanımı (Yunanca ve Latince); madencilik; Zeus kültleri.

\section{Two Galatian Cults in Dacia}

Abstract

An unpublished inscription from Ancyra or its territory contains a dedication to Zeus Erusenos. This deity is also attested on two Latin inscriptions found in Roman Dacia (Roumania), and the cult, like several other local cults from Galatia or eastern Bithynia, was exported from Asia Minor to the new province of Dacia after it was conquered and annexed by the emperor Trajan. A Greek dedication to Zeus Sittakomikos recorded in Dacia should be emended to Zeus Heptakomikos, and identified with the cult of Zeus of the Seven Villages (Zeus Heptakomeitôn), who was worshipped on the imperial estate called the Chôra Considiana in western Galatia. Many of the Galatian migrants may have been involved in mining and quarry work.

Keywords: Ancyra; Galatian migrants; language use (Greek and Latin); mining; Zeus cults. 